\title{
Gibbons: SSC should have been international
}

Washington. The lack of international funding for the US Superconducting Super Collider (SSC) is "a mistake that we should never make again", says presidential science and technology adviser John Gibbons, but the \$10-billion project will nevertheless continue.

Gibbons says that the funding prospects for the proton-proton accelerator being built in Texas are "a mess" even though the Clinton administration decided earlier this year to prolong construction for three years, giving itself more time to attract international contributors and to make sure that all technical questions have been answered. With a fifth of the money already committed, however, Gibbons says that "we're simply going to have to try to work our way through" any more problems that arise and, if necessary, "we're just going to have to pay for it ourselves".

Congress will shortly take up the president's budget request of $\$ 640$ million for the SSC in fiscal year 1994, which begins on 1 October. Gibbons admits that "it's going to be tough choice" in the context of efforts to reduce the $\$ 300$-billion federal deficit, but he says that he is no longer concerned about possible cost overruns and technical difficulties involved in manufacturing the 8,500 dipole magnets that will line the SSC's 54-milelong tunnel.

Gibbons discussed with Nature last week the balance of federal research among agencies, the role of the national laboratories and the emerging structure of his 40-member staff at the Office of Science and Technology Policy (OSTP), which he directs. He also predicted that an announcement would be made "very soon" on the president's nominees to head the National Science Foundation (NSF) and the National Institutes of Health (NIH).

The Clinton administration has been criticized, in particular by biomedical researchers, for keeping science in the shadows of a widely publicized technology initiative and a supplemental appropriations package (since rejected by Congress) emphasizing the role of technology in creating jobs. Gibbons, a physicist who joined the administration in January after spending 13 years as director of the congressional Office of Technology Assessment, defends the administration's policies and asserts that "science is probably the most productive investment you can make".

Gibbons says that he is "very troubled" by the allocation of the $\$ 73$ billion that the government will spend this year on research and development, adding that the US investment in science and technology — with its 59:41 balance between military and civil- ian research -- "does not match our national goals". However, when asked whether basic-research agencies such as NSF and NIH should receive more money, Gibbons says "not necessarily", confessing that "I'm not sure what the magic number is for basic research".

One sector often mentioned as ripe for pruning are the 725 federal laboratories, in particular some of the national laboratories run by the Department of Energy (DOE).

\section{IMAGE UNAVAILABLE FOR COPYRIGHT REASONS}

Gibbons wants many good men and women.

Although Gibbons says that he would be hard-pressed to defend the continued existence of one, much less two, nuclear weapons laboratories - currently at Los Alamos, New Mexico, and Livermore, California he does not favour closing any of the DOE laboratories.

"I think that the notion of closing or opening is not as critical as what you do with those resources", he says. "You need to look at the nature of the resource, what kinds of people and equipment there are and the optimal way to use them. That's the issue facing DOE."

Gibbons places great importance on the number of cooperative research agreements between federal laboratories and industry and says that a laboratory's ability to attract 10-20 per cent of its budget from the private sector "poses a good market test" of the utility of its research programme. But he says that such a test "is only a start" and that additional information is needed before the fate of any laboratory is decided.

As director of OSTP, Gibbons is respon- sible for coordinating federal spending on science and technology. He says that his job is made easier by the absence of "warring ideologies" like those that confounded the previous two administrations on such issues as industrial policy and global warming and that he hopes to build on the work of his predecessor, D. Allan Bromley, in creating interagency panels known as Federal Coordinating Committees for Science, Engineering and Technology (FCCSET).

These panels are involved in six research initiatives - covering global climate change, biotechnology, advanced manufacturing, science education, high-performance computing and materials - with a combined budget next year of $\$ 12.5$ billion (see Nature 362, 776; 1993).

The White House has just begun a review of these initiatives as the first step in preparing the 1995 budget, and Gibbons says that it is likely that some, in particular advanced materials, may not be retained in their present form. To sharpen that analysis, a second group has been formed consisting of the deputy and assistant secretaries from each of the agencies funding research in one or more of the areas. This deputies' group, Gibbons says, provides "one-stop shopping" for those needing information about FCCSETrelated efforts at each agency as well as a review of existing programmes.

Gibbons has played a leading role in finding an NSF director to succeed Walter Massey, who left two months ago to become provost of the University of California system. He admits to being "disappointed" when his first choice, astronomer Sandra Faber, decided to remain at the University of California at Santa Cruz, and says that next time "I'm going to make sure that the person is ready to say yes" before the post is offered. (Faber says that she was "very interested" in the NSF post but that two events later this year involving projects on which she has worked for a decade - the start of operation of the Keck telescope and the repair of the Hubble space telescope led her to decline the offer.) But he is even more disturbed by the paucity of qualified applicants.

"If there is any shortage in science, it's of people able and willing to do jobs like this one, or at OTA, NSF or NIH", he says. "One of the problems is that the system doesn't provide many opportunities at lower levels to acquire the necessary skills." Although such jobs are not for everyone, he says that not enough senior researchers "feel an obligation to apply what they have learned and experienced" outside the laboratory.

Jeffrey Mervis 